\title{
PENGARUH BIAYA OPERASIONAL PENDAPATAN OPERASIONAL (BOPO) DAN RISIKO KREDIT (NPL) TERHADAP PROFITABILITAS (ROA)
}

\author{
Meliana Dwi Lestari \\ 1,2Universitas Singaperbangsa Karawang \\ 1710631030111@student.unsika.ac.id \\ Gusganda Suria Manda \\ ${ }^{1,2}$ Universitas Singaperbangsa Karawang
}

\begin{abstract}
Banking is an institution that is very important for the community in its efforts to grow the economy and the level of welfare. The population determined by the author is the banking sector companies listed on the IDX for the period 2012 to 2019, while the sample used is the banking company PT. Bank Mandiri (Persero) Tbk Period 2012-2019. This study uses Multiple Linear Regression Analysis. The steps carried out are classical assumption test, normality, multicollinearity, heteroscedasticity, autocorrelation, $t$ test, and $f$ test. Researchers use quantitative methods in conducting research and use secondary data derived from the quarterly financial statements of PT. Bank Mandiri for the period 2012 to 2019. The results of the study illustrate that the BOPO variable (XI) has a partial effect on the Profitability variable (Y) with a tvaluetable $(-21,751<8.942)$ and a significance value $(0.00<0.05)$. Next, the NPL variable $(X 2)$ has a partial effect on the Profitability variable $(Y)$ with a tvaluetable $(-12,415<8.942)$ and a significance value $(0.00<0.05)$. And also together, the variable $X$ in this study affects the variable $Y$ with a value of Ftable $(154,128>5,329)$.
\end{abstract}

Keywords : BOPO, NPL, Profitability

\section{PENDAHULUAN}

Perbankan menjadi suatu lembaga yang sangat penting bagi masyarakat yang di dalam usahanya menumbuhkan perekonomian serta tingkat kesejahteraan. Pada perbankan maupun non perbankan, penjelasan mengenai risiko kredit terlihat lebih dipersempit lagi. Untuk mengendalikan risiko kredit, perlu melalui berbagai tahapan dalam manajemen risiko perbankan. Tahapan tersebut dilakukan dengan pemanfaatan sumber daya pada bank, seperti SDM dan sumber daya yang berasal dari teknologi. Apabila sumber daya tersebut dimanfaatkan dengan sebaik-baiknya, maka tujuan untuk meminimalisir suatu risiko kredit dapat tercapai. Di zaman seperti ini, perusahaan harus mampu bertahan dari para pesaing bisnisnya dengan selalu mencermati keadaan pasar dan kerugian yang akan terjadi. Kemudian, perusahaan juga harus mampu memperhitungkan laba yang harus didapat sesuai dengan tujuan perusahaan.

\section{KAJIAN PUSTAKA \\ PENGEMBANGAN HIPOTESIS \\ Profitabilitas (Return On Asset)}

Rivai et al. (2013) menjelaskan dalam rasio Profitabilitas berfungsi untuk mengukur kekuatan perusahaan untuk mendapatkan laba yang berasal dari aset yang dimiliki. Atmoko et al. (2018) salah satu rasio dari profitabilitas yaitu ROA mampu menilai total keuntungan bersih yang didapat perusahaan yang berasal dari investasi pada aktiva.

\section{Pengaruh Biaya Operasional Pendapatan Operasional Terhadap Profitabilitas}

Menurut Riyadi (2006) BOPO berfungsi 
untuk membandingkan biaya operasional dan pendapatan operasional. Nilai pada rasio BOPO akan menunjukkan kemampuan manajemen perusahaan dalam bekerja. Apabila nilai tersebut rendah, maka hal itu baik. Kemudian, BOPO juga berfungsi dalam menunjukkan keefisienan perusahaan dalam mengeluarkan biaya operasional. Apabila biaya operasional dapat dikendalikan dengan efisien, maka pada perusahaan tersebut tidak dalam situasi yang sedang mengalami masalah.

Munawir (2010) menjelaskan bahwa pengukuran BOPO dapat dilakukan melalui perbandingan biaya operasional dengan pendapatan operasional. BOPO berfungsi dalam mengetahui keefisienan manajemen dalam mengatur biaya operasional. Apabila biaya operasional pada bank semakin efisien, maka situasi pada bank tersebut sangat baik (Sukarno \& Syaichu, 2006). Riset yang dikerjakan oleh Putri (2020) mendapatkan hasil bahwa terdapat pengaruh variabel BOPO terhadap Profitabilitas. Sependapat dengan pengamatan yang dikerjakan oleh Pinasti \& Mustikawati (2018) dengan memberikan hasil bahwa BOPO berpengaruh terhadap Profitabilitas.

H1: Biaya Operasional Pendapatan Operasional berpengaruh terhadap Profitabilitas

\section{Pengaruh Risiko Kredit Terhadap Profitabilitas}

Dendawijaya (2009) menjelaskan rasio NPL berguna untuk mengukur resiko kredit pada perbankan dengan melihat tingkat nasabah mengembalikan pokok pinjaman serta membayar bunga yang sudah tertunda selama lebih dari setahun sejak jatuh tempo berdasarkan jadwal yang sudah dijanjikan. NPL bertujuan untuk mengetahui pembiayaan non lancar terhadap total pembiayaan. Batas nilai NPL pada perbankan yaitu 5\%, yang artinya apabila nilai NPL melebihi dari presentase tersebut maka dapat mempengaruhi tingkat kesehatan bank.

$$
\text { Rasio Non Perfoming Loan dapat }
$$
menggambarkan risiko kredit pada bank
(Agustiningrum, 2013). Masyud (2004) juga menjelaskan apabila sesudah kredit disalurkan kepada nasabah, maka bank memiliki kewajiban untuk memonitori nasabah dalam menggunakan kreditnya kemudian melihat kepatuhan serta usaha debitur dalam menjalankan kewajiban tersebut. Studi empirik yang dikerjakan oleh N. K. A. P. Putri et al., (2018) menjelaskan bahwa NPL berpengaruh terhadap Profitabilitas. Dan sependapat dengan penelitian tersebut, penelitian yang dilakukan oleh Putrianingsih \& Yulianto (2016) menjelaskan bahwa rasio NPL memiliki pengaruh terhadap Profitabilitas.

H2: Risiko Kredit berpengaruh terhadap Profitabilitas

\section{METODOLOGI PENELITIAN Populasi dan Sampel}

Populasi yang ditentukan oleh penulis yakni pada perusahaan sektor perbankan yang terdaftar di BEI periode 2012 hingga 2019, sedangkan sampel yang digunakan yaitu perusahaan perbankan PT. Bank Mandiri (Persero) Tbk Periode 2012-2019.

\section{Metode Analisis Data}

Pada penelitian ini, memiliki variabel BOPO $\left(\mathrm{X}_{1}\right)$, NPL $\left(\mathrm{X}_{2}\right)$, dan Profitabilitas (Y). Penelitian ini memakai Analisis Regresi Linear Berganda. Dengan tahapan yang dilakukan yaitu uji asumsi klasik, normalitas, multikolinearitas, heteroskedastisitas, autokorelasi, uji t, serta uji f. Peneliti menggunakan metode kuantitatif dalam melakukan penelitian serta menggunakan data sekunder yang berasal dari laporan keuangan Triwulan PT. Bank Mandiri Periode 2012 hingga 2019. Laporan Keuangan Triwulan didapatkan melalui website resmi BEI yaitu www.idx.co.id. Perhitungan data dilakukan dengan alat statistik berupa SPSS.

\section{HASIL DAN PEMBAHASAN}

\section{Analisis Deskriptif}

Tabel 1 Analisis Deskriptif 


\begin{tabular}{l|l|l|l|l|l}
\hline \multicolumn{7}{l}{ Descriptive Statistics } \\
\hline & N & Minimum & Maximum & Mean & Std. Deviation \\
\hline BOPO & 32 & 62,17 & 80,94 & 67,9716 & 5,10899 \\
\hline NPL & 32 &, 37 & 1,38 &, 7159 &, 30542 \\
\hline ROA & 32 & 1,95 & 3,66 & 3,0953 &, 45316 \\
\hline
\end{tabular}

Sumber: data diolah oleh penulis, 2020

Hasil yang didapatkan melalui analisis deskriptif menjelaskan total data yang dipakai oleh penulis yaitu sebesar 32 sampel berasal dari laporan keuangan triwulan PT Bank Mandiri (Persero) tahun 2012-2019.

\section{Uji Asumsi Klasik}

Tabel 2 Uji Normalitas

\begin{tabular}{l|l}
\hline \multicolumn{2}{c}{ One-Sample Kolmogorov-Smirnov Test } \\
\hline \multicolumn{2}{|c}{ Unstandardized Residual } \\
\hline $\mathrm{N}$ & 32 \\
\hline Asymp. Sig. (2-tailed) & 0,200 \\
\hline
\end{tabular}

Sumber: data diolah oleh penulis, 2020

Pengujian normalitas yang dilakukan menggunakan Kolmogorov- Smirnov (K-S) mendapatkan hasil nilai signifikansi sebesar
0,200. Dari hal tersebut, menggambarkan data yang dipakai oleh penulis terdistribusi secara normal.

Tabel 3 Uji Multikoliniearitas

\begin{tabular}{|c|c|c|c|}
\hline \multicolumn{4}{|c|}{ Coefficients $^{\mathrm{a}}$} \\
\hline \multirow{2}{*}{\multicolumn{2}{|c|}{ Model }} & \multicolumn{2}{|c|}{ Collinearity Statistics } \\
\hline & & Tolerance & VIF \\
\hline \multirow[t]{2}{*}{1} & BOPO & ,249 & 4,010 \\
\hline & NPL & ,249 & 4,010 \\
\hline
\end{tabular}

Sumber: data diolah oleh penulis, 2020

Pengujian multikoliniearitas memperoleh hasil yaitu tidak adanya hubungan antar variabel independen yang ditunjukkan dengan nilai toleransi diatas 0,1 dan nilai VIF yang lebih kecil dari 10.

Tabel 4 Uji Autokorelasi

\begin{tabular}{l|l}
\hline Model & Durbin-Watson \\
\hline 1 &, 858 \\
\hline
\end{tabular}

Sumber: data diolah oleh penulis, 2020 
Pengujian dengan melalui autokorelasi mendapatkan nilai DW sebesar 0.858 , serta didapatkan nilai du sebesar 1,994. Artinya, nilai yang diuji menggunakan teknik Durbin Watson sebesar 0,858 < 1,994 (du) serta < (4-du) 4-1,944 $=2,802$ maka hal tersebu menandakan tidak adanya autokorelasi pada penelitian ini.

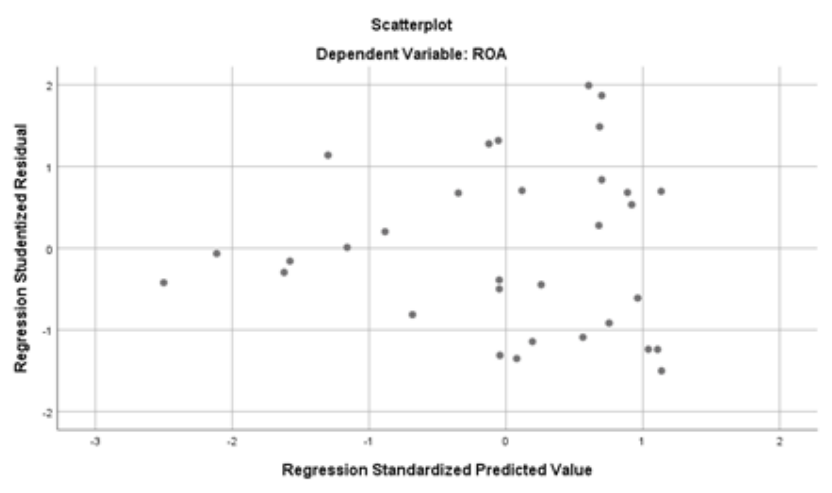

Sumber: data diolah oleh penulis, 2020

Gambar 1. Hasil Uji Heteroksiditas

Berdasarkan hasil uji heteroksiditas, jika titik titik yang berada diatas nol maupun dibawah nol itu menandakan bahwa model regresi yang dipakai pada penelitian ini terbebas dari heteroskedastisitas.

\section{Analisis Regresi Linear Berganda}

Tabel 5 Uji F

\begin{tabular}{l|l|l|l}
\hline \multicolumn{2}{l|}{ Model } & F & Sig. \\
\hline \multirow{3}{*}{1} & Regression & 154,128 &, $000^{\mathrm{b}}$ \\
\cline { 2 - 4 } & Residual & & \\
\cline { 2 - 4 } & Total & & \\
\hline
\end{tabular}

Sumber: data diolah oleh penulis, 2020

Melalui pengujian F, didapatkan hasil yaitu Ho ditolak dan Ha diterima, hal ini dapat terlihat dari nilai Fhitung 154,128 > Ftabel 5,329. Dari hasil tersebut penulis berkesimpulan yaitu variabel BOPO dan variabel NPL memiliki pengaruh terhadap variabel dependen
Profitabilitas. Riset yang dikerjakan oleh Avrita \& Pangestuti (2016) memiliki hasil yang sama dengan mengatakan bahwa secara simultan variabel CAR, NPL, LDR, NIM, dan BOPO berpengaruh secara bersama sama terhadap Profitabilitas

Tabel 6 Analisi Regresi Linear Berganda

\begin{tabular}{|c|c|c|c|c|c|}
\hline \multicolumn{2}{|c|}{ Model } & \multicolumn{2}{|c|}{ Unstandardized Coefficients } & \multirow[t]{2}{*}{$\mathrm{t}$} & \multirow[t]{2}{*}{ Sig. } \\
\hline & & $\mathrm{B}$ & Std. Error & & \\
\hline \multirow[t]{3}{*}{1} & (Constant) & 7,694 &, 369 & 20,861 &, 000 \\
\hline & BOPO &,- 063 & 006 & $-9,896$ &, 000 \\
\hline & NPL &,- 445 & 106 & $-4,178$ &, 000 \\
\hline
\end{tabular}

Sumber: data diolah oleh penulis, 2020 


\section{Pengaruh Biaya Operasional Pendapatan Operasional Terhadap Profitabilitas}

Melalui pengujian secara parsial dengan menggunakan uji $\mathrm{t}$, didapatkan hasil bahwa $\mathrm{t}$ hitung bernilai $-21,751$ yang nilainya kurang dari $\mathrm{t}$ tabel sebesar 8,942. Dari hasil tersebut dapat diambil kesimpulan bahwa Ho ditolak dan $\mathrm{Ha}$ diterima. Dan didapatkan pula nilai signifikansi pada variabel $\mathrm{BOPO}$ sebesar 0,000 yang nilainya kurang dari 0,05 dan nilai B menunjukkan ke arah negatif yaitu $-0,086$. Keseluruhan dari penjelasan diatas, berarti pada variabel BOPO memiliki pengaruh signifikan secara negatif terhadap variabel Profitabilitas. Sesuai dengan hasi penelitian oleh Chandra \& Anggraini (2020) yang memiliki hasil bahwa BOPO memiliki pengaruh yang negatif terhadap ROA. Penelitian yang dilakukan Peling \& Sedana (2018) mendapatkan hasil yang serupa dengan menyebutkan bahwa variabel BOPO memiliki pengaruh yang negatif terhadap ROA. Yang berarti, apabila bank mampu mengefiesenkan biaya operasional yang mereka miliki, maka bank tersebut dapat meminalisirkan kerugian dan laba yang akan didapatkan sesuai dengan apa yang diinginkan. Namun hasil yang berbeda dijelaskan oleh Gunawan et al. (2020) yang memberikan pendapat bahwa variabel BOPO tidak berpengaruh terhadap variabel Profitabilitas.

\section{Pengaruh Risiko Kredit Terhadap Profitabilitas}

Melalui pengujian secara parsial dengan menggunakan uji $\mathrm{t}$, didapatkan hasil bahwa $\mathrm{t}$ hitung bernilai $-12,415$ yang nilainya kurang dari $\mathrm{t}$ tabel sebesar 4,067. Dari hasil tersebut dapat diambil kesimpulan bahwa Ho ditolak dan $\mathrm{Ha}$ diterima. Dan didapatkan pula nilai signifikansi pada variabel NPL sebesar 0,000 yang nilainya kurang dari 0,05 dan nilai B menunjukkan ke arah negatif yaitu $-1,357$. Keseluruhan dari penjelasan diatas, berarti pada variabel NPL memiliki pengaruh signifikan secara negatif terhadap variabel Profitabilitas. Hasil ini sesuai dengan pendapat yang dipaparkan oleh Hutagalung et al. (2013) yang mengatakan variabel NPL memiliki pengaruh secara negatif terhadap Profitabilitas.
Sedangkan pendapat yang berbeda diutarakan oleh Zulfikar (2014) yang mengatakan bahwa variabel NPL tidak memiliki pengaruh terhadap variabel Profitabilitas.

\section{KESIMPULAN}

Dari hasil dan pembahasan yang sudah dijelaskan oleh penulis, oleh karena itu dapat ditarik kesimpulan yakni. Pertama, variabel BOPO berpengaruh negatif terhadap variabel Profitabilitas. Hal tersebut dapat dilihat melalui nilai thitung yaitu $-21,751<\mathrm{t}_{\text {tabel }}$ yaitu 8.942 dan nilai signifikansi yaitu $0,000<0,05$, serta nilai $\mathrm{B}$ yaitu -0.086 yang memiliki arah negatif. Kedua, variabel NPL berpengaruh negatif terhadap variabel Profitabilitas. Hal tersebut dapat dilihat melalui nilai thitung yaitu $-12,415<t_{\text {tabel }}$ yaitu 4,067 dan nilai signifikansi yaitu $0,000<0,05$, serta nilai $\mathrm{B}$ yaitu $-1,357$ yang memiliki arah negatif. Ketiga, variabel BOPO dan NPL secara simultan memiliki pengaruh terhadap variabel Profitabilitas. Hal tersebut dapat dilihat melalui nilai Fhitung 154,128 > Ftabel 5,329.

Saran yang mungkin bisa diberikan bagi perusahan PT. Bank Mandiri (Persero) Tbk. yang diharapkan untuk selalu memperhatikan biaya operasional pendapatan operasional (BOPO) sesuai dengan ketentuan Bank Indonesia yang harus berada $<90 \%$, hal ini berguna untuk melihat tingkat efisien suatu bank dalam mengeluarkan biaya operasional yang mereka miliki. Kemudian, PT Bank Mandiri (Persero) Tbk. harus juga selalu menjaga nilai NPL dengan tujuan agar dapat melihat tingkat kredit macet yang diberikan kepada nasabah. Jika presentase NPL lebih dari 5\%, hal tersebut akan sangat berpengaruh terhadap kesehatan yang dimiliki oleh PT. Bank Mandiri (Persero) Tbk.

\section{DAFTAR PUSTAKA}

Agustiningrum, R. (2013). Analisis Pengaruh CAR, NPL, Dan LDR Terhadap Profitabilitas Pada Perusahaan Perbankan. E-Jurnal Manajemen Universitas Udayana, 2(8), 255030.

Atmoko, A. S., Amboningtyas, D., \& Fathoni, A. (2018). Effect of LDR, NPL and BOPO on Profitabilities Based on CAR (Case Study on 
Banking Companies Listed on the Indonesia Stock Exchange Period 2013-2017). Journal of Management, 4(4), 1-17.

Avrita, R. D., \& Pangestuti, I. R. D. (2016). Analisis Pengaruh CAR, NPL, LDR, NIM, dan BOPO Terhadap Profitabilitas Bank (Perbandingan Bank Umum Go Public Dan Bank Umum Non Go Public Di Indonesia Periode Tahun 20112014). Diponegoro Journal of Management, 5(2), $1-13$.

https://ejournal3.undip.ac.id/index.php/djom/artic le/download/13964/13500

Chandra, S., \& Anggraini, D. (2020). Analysis of the Effect of CAR, BOPO, LDR, NIM and NPL on Profitability of Banks Listed on IDX for the Period of 2012-2018. Bilancia: Jurnal Ilmiah Akuntansi, 4(3), 298-309.

Dendawijaya, L. (2009). Manajemen Perbankan. Ghalia Indonesia.

Dirvi, D. S. A., Eksandy, A., \& Mulyadi, M. (2020). Pengaruh Growth Opportunity, Nwc, Cash Conversion Cycle, Ios Dan Leverage Terhadap Cash Holding. Jemasi: Jurnal Ekonomi Manajemen Dan Akuntansi, 16(1), 44-58.

Gunawan, I., Purnamasari, E. D., \& Setiawan, B. (2020). Pengaruh CAR, NPF, FDR, dan BOPO terhadap Profitabilitas (ROA) pada Bank Syariah Bukopin Periode 2012-2018. Jurnal Manajemen SDM Pemasaran, Dan Keuangan, 01(01), 19-36.

Hutagalung, E. N., Djumahir, \& Ratnawati, K. (2013). Analisa Rasio Keuangan terhadap Kinerja Bank Umum di Indonesia. Jurnal Aplikasi Manajemen, 11(1), 122-130.

Lestari, W. D., \& Setianegara, R. G. (2020). Analisis Pengaruh NIM, BOPO, LDR, DAN NPL Terhadap Profitabilitas (Studi Kasus Pada Bank Umum Yang Listed Di Bursa Efek Indonesia Periode 2014-2018). Keunis, 8(1), 82. https://doi.org/10.32497/keunis.v8i1.2136

Masyud, A. (2004). Asset Liability Management: Menyiasati Risiko Pasar dan Risiko Operasional dalam Perbankan. PT. Elex Media Komputindo.

Munawir. (2010). Analisis Laporan Keuangan (Edisi Keem). Liberty.
Peling, I., \& Sedana, I. (2018). Pengaruh LDR, NPL, dan BOPO Terhadap Profitabilitas tahun 20092016, Bali. Jurnal Manajemen UNUD, 7(6), 2999-3026.

Pinasti, W. F., \& Mustikawati, R. I. (2018). Pengaruh CAR, BOPO, NPL, NIM Dan LDR Terhadap Profitabilitas Bank Umum Periode 2011-2015. Nominal, Barometer Riset Akuntansi Dan Manajemen, https://doi.org/10.21831/nominal.v7i1.19365

Putri, A. S. (2020). Analisis Pengaruh CAR, NPL, BOPO, LDR dan NIM terhadap Profitabilitas Pada Perbankan. Jurnal Ilmu Dan Riset Manajemen, 8(7).

Putri, N. K. A. P., Wiagustini, L. P., \& Abundanti, N. N. (2018). Pengaruh NPL, CAR Dan BOPO Terhadap Profitabilitas Pada Bpr Di Kota Denpasar. E-Jurnal Manajemen Universitas Udayana, 7(11), 6212. https://doi.org/10.24843/ejmunud.2018.v07.i11.p 15

Putrianingsih, D. I., \& Yulianto, A. (2016). Pengaruh Non Performing Loan (NPL) dan Capital Adequacy Ratio (CAR) terhadap Profitabilitas (Studi Kasus pada Perusahaan Perbankan yang Terdaftar di BEI Periode 2010-2013). Management Analysis Journal, 5(2), 110-115. https://doi.org/10.15294/maj.v5i2.7622

Rivai, V., Basir, S., Sudarto, S., \& Veithzal, A. P. (2013). Commercial Bank Management: Manajemen Perbankan dari Teori ke Praktik (Edisi Pert). Rajawali.

Riyadi, S. (2006). Banking Assets and Liability Management (Edisi Keti). Fakultas Ekonomi Universitas Indonesia.

Sukarno, K. W., \& Syaichu, M. (2006). Analisis Faktor-Faktor Yang Mempengaruhi Kinerja Bank Umum Di Indonesia. Jurnal Studi Manajemen \& Organisasi, 3(2).

Zulfikar, T. (2014). Pengaruh CAR, LDR, NPL, BOPO dan NIM Terhadap Kinerja Profitabilitas (ROA) Bank Perkreditan Rakyat Di Indonesia. EJournal Graduate Unpar, 1(2), 131-140. http://journal.unpar.ac.id/index.php/unpargraduat e/article/view/850 